\title{
The reliability of grazing rate estimates from dilution experiments: Have we over-estimated rates of organic carbon consumption by microzooplankton?
}

\author{
J. R. Dolan and K. McKeon \\ Marine Microbial Ecology Group, Laboratoire Oéanographique de Villefranche, CNRS UMR 7093, Université Paris VI, \\ Station Zoologique, B P 28, F-06230 Villefranche-Sur-Mer, France
}

Received: 4 November 2004 - Published in Ocean Science Discussions: 18 November 2004

Revised: 1 February 2005 - Accepted: 8 February 2005 - Published: 11 February 2005

\begin{abstract}
According to a recent global analysis, microzooplankton grazing is surprisingly invariant, ranging only between 59 and $74 \%$ of phytoplankton primary production across systems differing in seasonality, trophic status, latitude, or salinity. Thus an important biological process in the world ocean, the daily consumption of recently fixed carbon, appears nearly constant. We believe this conclusion is an artefact because dilution experiments are 1) prone to providing over-estimates of grazing rates and 2) unlikely to furnish evidence of low grazing rates. In our view the overall average rate of microzooplankton grazing probably does not exceed $50 \%$ of primary production and may be even lower in oligotrophic systems.
\end{abstract}

\section{Introduction}

Recently Calbet and Landry (2004) presented a global analysis of the impact of microzooplankton grazing based on the results of "dilution" grazing experiments. They found that microzooplankton grazing was surprisingly invariant, ranging only between 59 and $74 \%$ of phytoplankton primary production across systems differing in seasonality, trophic status, latitude, or salinity. If $64 \%$ of the carbon fixed photosynthetically per day is consumed by microzooplankton there appears to be little left for any direct forms of carbon export or fueling whatever type of food web co-occurs with the microzooplankton, from bacteria to nekton. We believe this conclusion is an artefact because dilution experiments are 1) prone to providing over-estimates of grazing rates and 2) unlikely to furnish evidence of low grazing rates.

The dilution approach relies on the reduction of encounter rates between phytoplankton and their microzooplankton grazers. Natural water samples are amended with varying

Correspondence to: J. Dolan

(dolan@obs-vlfr.fr) proportions of filtered seawater creating a dilution series, and grazing rate is estimated as the increase in apparent phytoplankton growth rate with dilution factor. Microzooplankton grazing rate is estimated as the slope of a regression of apparent phytoplankton growth in the various dilutions against dilution factor. Growth rate of the phytoplankton is estimated as apparent growth rate extrapolated to $100 \%$ dilution (growth in the absence of grazers).

While elegant, the dilution method (Landry and Hassett, 1982) is not without problems. The dilution approach was also proposed for estimating bacterioplankton growth rates (Kirchman et al., 1982) but is no longer employed as bacterioplankton communities change in dilution treatments, exhibiting growth patterns of an enrichment culture (e.g. Fuchs et al., 2000). In studies of microzooplankton grazing, results are often uninterpretable, judging from the fact that publications commonly report instances of uninterpretable results, i.e. plotting apparent phytoplankton growth against dilution factor does not yield a significant regression. Published "failure rates" range from 6 to $74 \%$ of the experiments run (Caron and Dennett, 1999; Caron et al., 2000; Gaul et al., 1999, Gifford et al., 1995; Kamiyama, 1994; Kuipers and Witte, 1999; Landry et al., 1995; Lessard and Murrell, 1998; Murrell and Hollibaugh, 1998; Reckermann and Veldhuis, 1997).

Some non-significant results are likely due to the fact that slight slopes, or low grazing rates, are difficult to detect with regression analysis using the small $n$ values commonly employed ( $8-15$ bottles). Compounding this difficulty is the fact that detecting low grazing rates necessitates distinguishing slight differences in start and end chlorophyll concentrations which is especially difficult in the highly dilute treatments.

Another problem which has received some attention is the possibility that grazing pressure may not be linearly related to dilution factor because 1) per-capita consumption rates of microzooplankton may differ in the different dilution treatments (Gallegos 1989; Evans and Paranjape 1992) and/or 2) grazer concentration may not be linearly related to dilution

(C) 2005 Author(s). This work is licensed under a Creative Commons License. 
factor throughout the incubation time. Data exists with regard to the response of the grazer community to dilution in terms of apparent growth and mortality (Dolan et al., 2000). It has been stated that the combined effects of grazer mortality in dilute treatments and growth in undiluted treatments (Gallegos 1989) can result in an over-estimation of grazing rate and that the over-estimation may be common, especially in low chlorophyll waters (Dolan et al., 2000).

Given the surprising results of Calbet and Landry concerning the near-constancy of microzooplankton grazing, and its apparent magnitude, it is worthwhile examining the results of dilution experiments for evidence of over-estimation of microzooplankton grazing rates. To this end, we analyzed results from dilution experiments which included data on the grazer population, more precisely initial ciliate concentrations. Of all potential grazers whose activities are estimated in dilution experiments, data on ciliate concentrations in undiluted waters was most commonly reported. Consequently, we employed ciliate concentration as reasonable proxy estimate of total grazer concentration. The basic approach was to determine if a reported grazing rate (for the entire microzooplankton community) was "reasonable" with regard to the initial ciliate concentrations.

For each experiment which reported ciliate abundance we calculated the average individual ciliate grazing rate $(\mu 1$ ciliate $^{-1} \mathrm{~h}^{-1}$ ) based on grazing rate and ciliate abundance. This experimental parameter was then compared to a maximum filtration rate for ciliates, artificially inflated to account for the activity of other microzooplankters: heterotrophic dinoflagellates and other herbivorous flagellates. We also examined the effect of dilution on ciliate microzooplankton from a low chlorophyll environment, the N.W. Mediterranean to verify the results found with ciliates from a eutrophic estuary. We conclude that grazing rates estimated using the dilution approach have probably been over-estimated, especially in low chlorophyll waters.

\section{Methods}

Literature reports were used to assemble a data base of parameters from individual dilution experiments consisting of: 1) initial concentration of chlorophyll, 2) concentration of ciliate microzoooplankton (cells $\mathrm{ml}^{-1}$ ), 3) chlorophyll-based grazing rate $\left(\mathrm{g} \mathrm{d}^{-1}\right)$ and 3 ) chlorophyll-based phytoplankton growth rate $\left(k \mathrm{~d}^{-1}\right)$. Only experiments with significant regression relationships $(p<0.05)$ were included. The data base consisted of a set of 185 corresponding values, for the most part a subset of the 788 experiments analyzed by Calbet and Landry (2004). Data from 2 studies not considered in the Calbet and Landry analysis, Verity and Vernet (1992) and Olson and Strom (2002) were included. It should be noted that the overwhelming majority of reports of dilution experiments contain no data on grazer abundance; a few gave data on grazer biomass but not cell abundance.
Apparent ciliate clearance rates were calculated by a) dividing reported per day grazing rate by 24 , to obtain an hourly rate $-g \mathrm{~h}^{-1}$, b) dividing $g \mathrm{~h}^{-1}$ by ciliates $\mathrm{ml}^{-1}$ to obtain $\mathrm{ml}$ cleared per ciliate per hour, c) multiplying the $\mathrm{ml}$ clearance rate by 1000 to obtain clearance as $\mu$ ciliate $^{-1}$ $\mathrm{h}^{-1}$. These calculations assign all grazing activity exclusively to ciliates.

First, simple scatter plots and linear regression of logtransformed values was used to investigate possible interrelationships. Further analysis was conducted separating data from individual experiments associated with very high ciliate clearance rates $\left(>20 \mu \mathrm{l}\right.$ ciliate $\left.^{-1} \mathrm{~h}^{-1}\right)$ from those yielding acceptable clearance rates $\left(\leq 20 \mu \mathrm{l}\right.$ ciliate $\left.^{-1} \mathrm{~h}^{-1}\right)$. A limit of $20 \mu \mathrm{l}$ was chosen as it is twice the rate of $10 \mu \mathrm{lh}^{-1}$ very rarely exceeded by ciliates (see Capriuolo et al 1991). The maximum average ciliate filtration rates was doubled to account for grazing by heterotrophic dinoflagellates, which can be as abundant as ciliates, but generally have maximum clearance rates of less than $1 \mu \mathrm{l} \mathrm{h}^{-1}$ (see Jeong, 1999) and herbivorous nanoflagellates, commonly present at abundances of about 1000 times that of ciliates, but with filtration rates of about $10 \mathrm{nl} \mathrm{h}^{-1}$ (see Dolan and Simek, 1999).

The effects of dilution on ciliate microzooplankton from a low chlorophyll environment were examined as part of experiments investigating the effects of turbulence on natural ciliate communities. We monitored changes in ciliate concentrations over a $24 \mathrm{~h}$ period in whole seawater compared to seawater diluted 9:1 with filtered water and then left undisturbed or subjected to turbulence. Water from a standard observation station in the Rade de Villefranche, Pt. B was obtained from $10 \mathrm{~m}$ depth. Chlorophyll concentration was approximately $0.3 \mu \mathrm{g} 1^{-1}$. Water for diluting the plankton community was prepared by filtering through GFF filters and used to create a solution of $90 \%$ GFF filtered seawater and $10 \%$ whole water. Samples were incubated in 21 Plexiglas containers; 3 containers were filled with whole seawater and 9 containers filled with $90 \%$ diluted seawater. Time zero samples of $100 \mathrm{ml}$ were taken and preserved with acid Lugols ( $2 \%$ final concentration) from each whole seawater container; the entire contents of 3 of the $90 \%$ diluted containers were preserved to estimate beginning ciliate ciliate abundance in the dilute treatment and check for immediate dilution effects.

The containers were incubated in a temperature controlled room at $17{ }^{\circ} \mathrm{C}$ under constant illumination provided by ceiling mounted fluorescent fixtures. An oscillating grid device, (described in Dolan et al., 2003) was used to generate smallscale turbulence estimated as about $0.5 \mathrm{~cm}^{2} \mathrm{~s}^{-3}$, for 3 of the 6 dilute water containers. The remaining 3 dilute water containers and the whole seawater containers were left undisturbed. After $24 \mathrm{~h}$, the entire contents of the dilute water containers and $100 \mathrm{ml}$ samples from the whole seawater containers was preserved with acid Lugols.

Ciliate concentrations were determined in $50 \mathrm{ml}$ aliquots using standard settling chambers and inverted microscopy for 

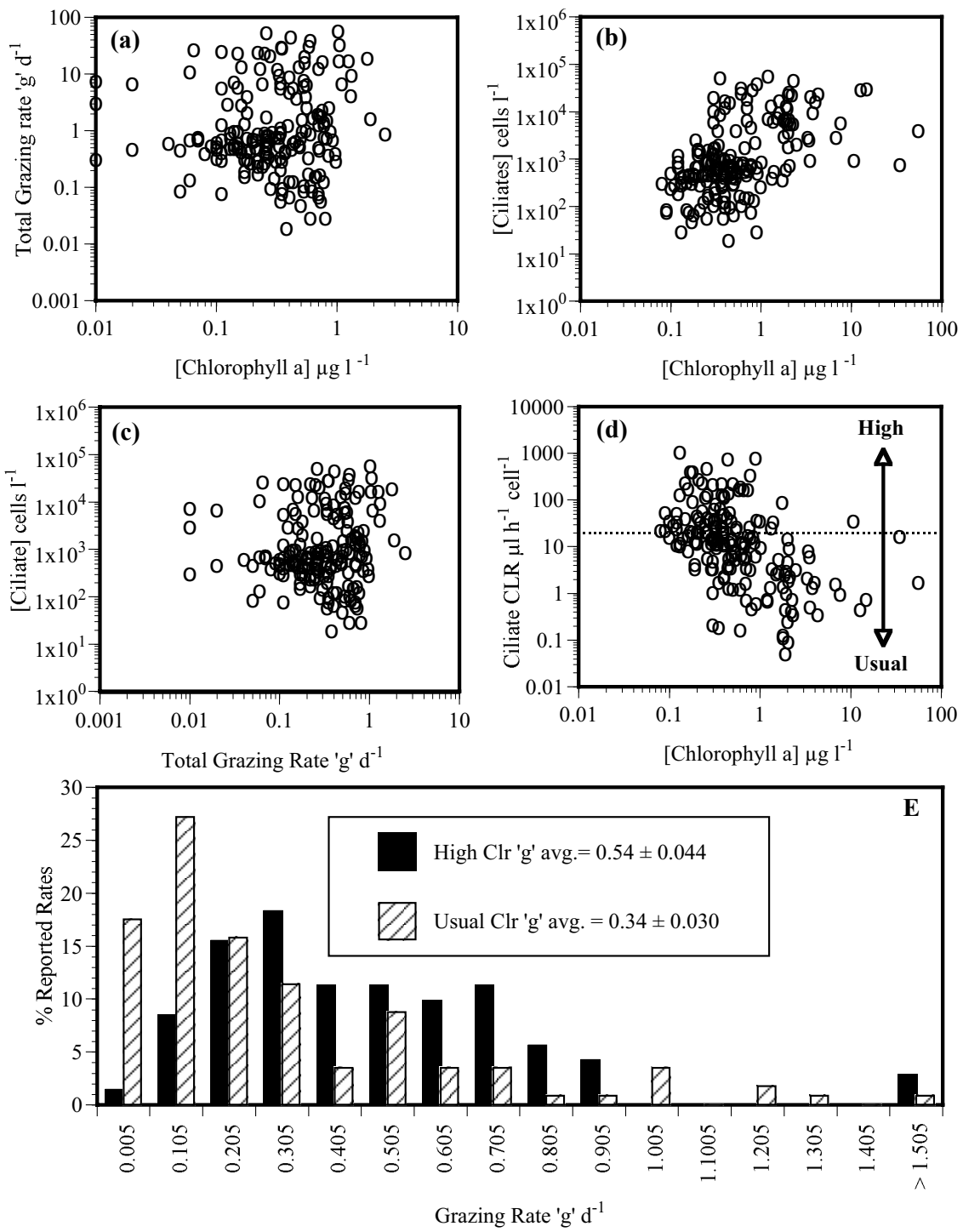

Fig. 1. Graphical presentation of data from dilution grazing experiments which reported initial chlorophyll $a$ and ciliate concentrations (Ayukai and Miller, 1998; Caron and Dennett, 1999; Dolan et al., 2000; Fileman and Burkill, 2001; Froneman and Perissinoto, 1996a, b; Gifford, 1988; Gifford et al., 1995; James and Hall, 1998; Landry and Hassett, 1982; Neuer and Cowles, 1994; Olson and Strom, 2002; Putland, 2000; Rivkin et al., 1999; Tamigneaux et al., 1997; Verity and Vernet, 1992; Verity et al., 1993; Verity et al., 1996). (a) Grazing rate as function of chlorophyll a concentration. 1(b) Ciliate concentration as a function of chlorophyll concentration. (c) Ciliate concentration as a function of grazing rate. (d) Calculated average ciliate clearance rate as a function of chlorophyll concentration. Dotted line divides the rate estimates in two fields of "Usual" and "High" clearance rates; (e) shows the frequency distributions of the two sets of grazing rates, see text for details.

the whole water samples. For the diluted community a 2step concentration procedure was used. The entire volume of the container was settled in a graduated cylinder for $72 \mathrm{~h}$ and then the top $1900 \mathrm{ml}$ removed though careful siphoning. The remaining water was examined in $50 \mathrm{ml}$ aliquots following standard procedures. Ciliates enumerated were categorized in various size-shape categories. Here only total concentrations are reported as no distinct trends were evident with regard to any particular category of ciliate.

\section{Results}

Plots of data from the 185 experiments which included ciliate data showed that grazing rates were relatively invariant across a large gradient of chlorophyll concentrations, ranging over 4 orders of magnitude (Fig. 1a). In contrast, ciliate grazer and chlorophyll concentration were positively related, $r=0.51 ; p<0.0001$, (Fig. 1b). Thus, data from dilution experiments suggests that grazing rates are independent of grazer abundance (Fig. 1c). Based on reported grazing rates 


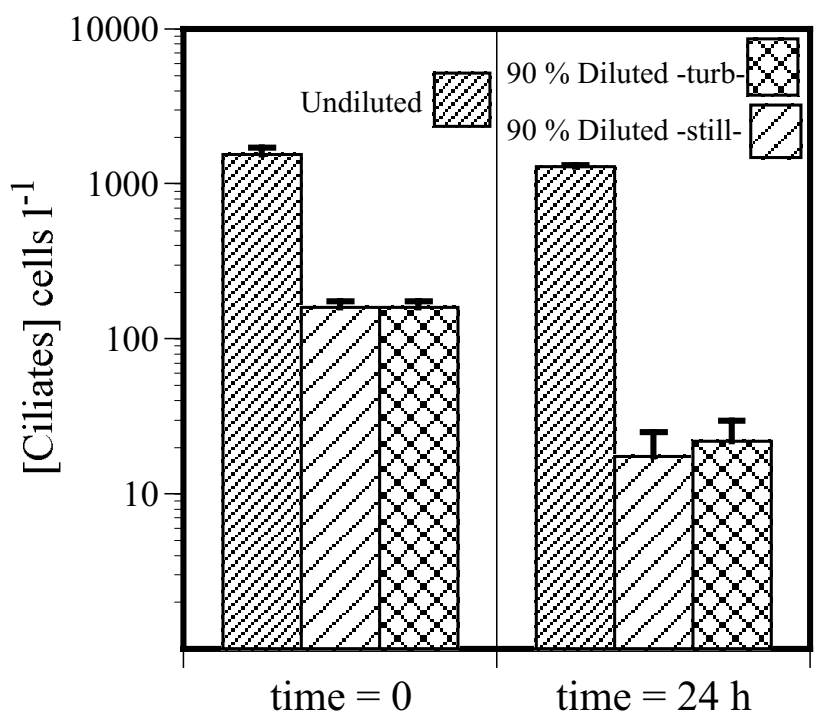

Fig. 2. Results of the experiment examining the effects of dilution on a ciliate community from the NW Mediterreanean Sea. Average concentrations $( \pm \mathrm{sd})$ of ciliates, all morphotypes pooled, before and after $24 \mathrm{~h}$ of incubation of undisturbed whole seawater (Undiluted), seawater diluted 9:1 with GFF-filtered seawater and left undisturbed (90\% Diluted -still-) or subjected to small-scale turbulence $(90 \%$ -turb-). Note that high mortality of ciliates was associated with dilution in both still and turbulent treatments.

and ciliate concentrations, calculated ciliate clearance rates ranged from $10^{3}-10^{-1} \mu \mathrm{l}$ ciliate $^{-1} \mathrm{~h}^{-1}$ and declined with chlorophyll concentration, $r=-0.49 ; p<0.0001$ (Fig. 1d). Most high clearance rates $\left(>20 \mu\right.$ ciliate $\left.^{-1} \mathrm{~h}^{-1}\right)$ were derived from experiments in low chlorophyll waters. The average grazing rate from experiments yielding acceptable or "usual" clearance rates (accounting for the presence of herbivores other than ciliates) was $0.34 \mathrm{~d}^{-1}(n=114, s d=0.32)$, significantly different $(p<0.002)$ from the average of experiments yielding unrealistically high clearance rates, $0.54 \mathrm{~d}^{-1}$ $(n=71, s d=0.044)$. The higher average of the grazing rates associated with high clearance rates was not due to larger or more frequent occurrences of high $g$ values, but rather to a lack of low $g$ values (Fig. 1e). Thus, data from experiments derived largely from studies in low chlorophyll waters apparently inflates the overall average grazing rate. Using only the data from experiments which generated "usual" or acceptable clearance rate estimates, grazing rate is correlated with grazer abundance in the form of $g$ and ciliate concentration $(r=0.43, p<0.0001)$.

Results of the experiment examining the effect of dilution on a Mediterranean community of ciliates are shown in Fig. 2. The ciliate community, dominated by small $(15 \times 20 \mu \mathrm{m})$ oligotrichs, showed no significant change in concentration over the $24 \mathrm{~h}$ period in the whole seawater containers. In contrast, the ciliates displayed a very similar decrease in concentration when diluted in both the still and tur- bulence treatments. Calculating an "apparent growth rate" for the diluted containers yields a rate of about $-2 \mathrm{~d}^{-1}$.

\section{Discussion}

We reasoned that over-estimates of grazing would be detectable as high grazing rates associated with low ciliate concentrations, and that such rates could be identified as those yielding unrealistically high clearance rates (grazing rate divided by ciliate grazer concentration): those exceeding $20 \mu \mathrm{l}$ ciliate $^{-1} \mathrm{~h}^{-1}$. The limit of $20 \mu \mathrm{l}$ was based on a likely over-estimate of maximum average (oligotrichs and tintinnids) clearance of $10 \mu \mathrm{l}$ ciliate $\mathrm{h}^{-1}$, and then doubled to account for the grazing activity of co-occurring heterotrophic dinoflagellates and herbivorous nanoflagellates. Separating the grazing rate estimates using the independent criterion of clearance rate ( $\leq 20$ vs. $>20 \mu \mathrm{l}$ ), gave two significantly different sets of estimates based on a comparison of means. The set of grazing rates associated with acceptable or "usual" clearance rates gave a lower average rate of $0.34 \mathrm{~d}^{-1}$ compared to $0.54 \mathrm{~d}^{-1}$ for experiments in which calculated clearance rates were $\geq 20 \mu$ ciliate $^{-1} \mathrm{~h}^{-1}$. Of these latter experiment, identified as likely over-estimating grazing, most were run in low chlorophyll waters (Fig. 1d).

The analysis relies on identifying and removing high grazing rates associated with the presence of relatively few ciliates. Clearly this is inappropriate if A) ciliates in oligotrophic systems are resistant to dilution effects and/or exhibit very high average clearance rates, or B) microzooplankton communities in oligotrophic systems are fundamentally different in that ciliates are a minor component (i.e. exhibit very different ratios of ciliates to heterotrophic dinoflagellates or herbivorous nanoflagellates).

We found that dilution effects on ciliates from an oligotrophic system were similar to those found in ciliates from a eutrophic estuary; high dilution factors are associated with high mortality rates of ciliates over a $24 \mathrm{~h}$ period. In both cases (Fig. 2 and Dolan et al., 2000: Fig. 4) declines yield an apparent growth rate of about $-2 \mathrm{~d}^{-1}$ when food levels are diluted down to $10-20 \%$ of in situ concentrations. There are data suggesting that ciliate communities in oligotrophic areas differ in species composition from mesotrophic area communities (e.g. Dolan et al., 1999). However, we know of no data showing that "oligotrophic" ciliate or nanoflagellate clearance rates are higher than those of mesotrophic zones. Data on populations found in the oligotrophic eastern basin of the Mediterranean, suggests average ciliate clearance rates closer to 1 than $10 \mu \mathrm{l} \mathrm{cell}^{-1} \mathrm{~h}^{-1}$, based on food vacuole content (Pitta et al., 2001) and prey availability for natural populations (Christaki et al., 2001). Similarly, clearance rates of heterotrophic nanoflagellates from the same waters, about $8 \mu \mathrm{l} \mathrm{cell}{ }^{-1} \mathrm{~h}^{-1}$, appear very close to "normal" rates (Christaki et al., 2001). Thus, ciliates and flagellates in 
oligotrophic waters do not appear to exhibit unusually high clearance rates.

The second possible explanation for grazing rates to appear disproportionately large with a given ciliate concentration is that ciliates are a poor proxy measure of the grazer community, especially in oligotrophic waters. To evaluate this possibility we plotted ciliate concentrations versus those of heterotrophic nanoflagellates and heterotrophic dinoflagellates using reports from a wide variety of systems (Fig. 3). There is considerable scatter in the data, as to be expected when plotting "snapshots" of the abundances of predators and prey (ciliates and heterotrophic nanoflagellates) or competitors (ciliates and heterotrophic dinoflagellates). Furthermore, the different fixatives employed may have effected abundance estimates. However, it does appear that ciliate concentration is poor predictor of the abundance of heterotrophic nanoflagellates and dinoflagellates. Ciliate abundance appears to be particularly unrelated to the concentration of heterotrophic nanoflagellates when ciliate concentrations are low. Nonetheless, it is difficult to ascribe moderate to high grazing rates $\left(g>5 \mathrm{~d}^{-1}\right)$ in the presence of few ciliates $\left(<500\right.$ ciliates $\left.1^{-1}\right)$ without assigning unusually high clearance rates to heterotrophic flagellates.

We believe that dilution experiments can yield data suggesting grazing patterns quite different from those of natural communities because during dilution experiments the grazer community changes. Changes in the grazer community are especially probable in experiments conducted in low chlorophyll waters. We have shown that dilution be can expected to effect oligotrich ciliates based experimental data presented previously (Dolan et al., 2000) and here (Fig. 2) as well as simple consideration of known threshold prey concentrations (Dolan et al., 2000). Clearly, data is lacking for heterotrophic dinoflagellates and nanoflagellates on the possible effects of prey dilution. Generally speaking, high maximum growth rates are associated with high mortality rates. As both ciliates and nanoflagellates exhibit high growth rates there appears no a priori reason to expect starvation resistance to be higher in nanoflagellates compared to ciliates. On the other hand, heterotrophic dinoflagellates, with their relatively low maximum growth rates compared to ciliates and nanoflagellates, may be overall a relatively starvation-resistant group.

The magnitude of grazing rates can clearly influence the conclusions one draws with regard to the importance of the grazers. Calbet and Landry (2004) state that microzooplankton grazing accounts for an a cross-system average of $64 \%$ of primary production within a range of 59 to $74 \%$. Based on an analysis of, in our view, the most reliable data, and using the same methods as Calbet and Landry (2004), the overall average rate of microzooplankton grazing does not exceed $50 \%$ of primary production. However, more importantly, this may reflect a lower rate of phytoplankton consumption by micro and nanozooplankton in oligotrophic systems.

In reality, there is a great deal of uncertainty with regard to "who eats how much" in the plankton. A recent study
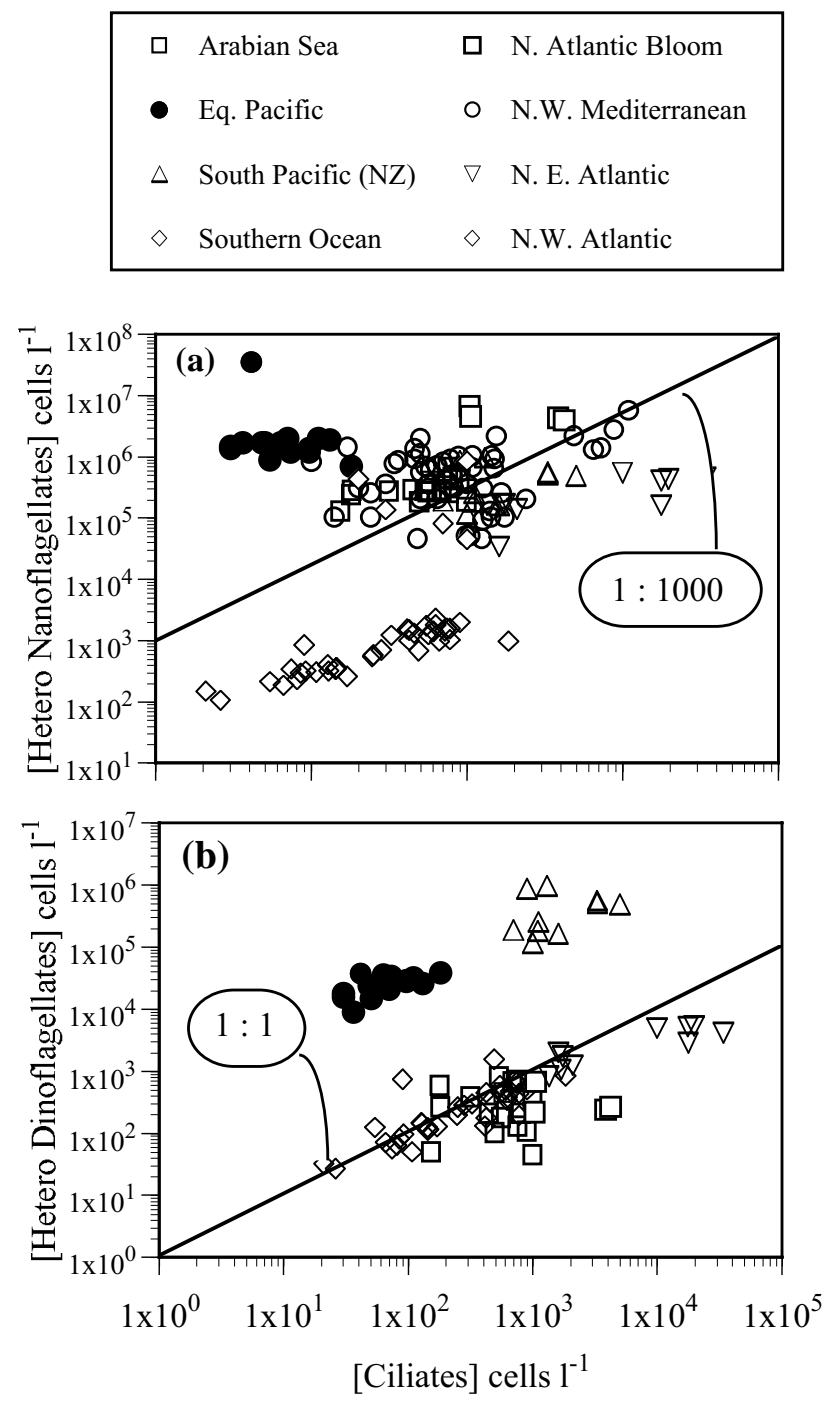

Fig. 3. Plots of reported ciliate concentrations versus heterotrophic nanoflagellate concentrations (A) and versus heterotrophic dinoflagellate concentrations (B) from a variety of systems: the Arabian sea (Caron and Dennett, 1999), equatorial Pacific (Verity et al., 1996), the south Pacific off New Zealand (Safi and Hall, 1997), the Southern Ocean (Froneman and Perissinotto 1996); the N. central Atlantic-N. Atlantic Bloom (Stoecker et al. 1994), the NNW Mediterranean (Mostajir et al., 1995); the N. E. Atlantic (Fileman and Burkill, 2001); the N. W. Atlantic (Putland, 2000). The line in panel A indicates the presumed 1:1000 relationship between ciliate and heterotrophic nanoflagellate concentrations and the line in panel B the presumed 1:1 relationship between the abundance of ciliates and heterotrophic dinoflagellates.

of mesozooplankton respiration in the global ocean resulted in the conclusion that metazoan zooplankton ingestion was equivalent to the wide ragne of $34-63 \%$ of primary production in terms of carbon (Hernandez-Leon and Ikeda, 2005). Exactly what carbon is eaten by metazoan zooplankton is far from certain. A large part of the carbon ingested by meta- 
zoan zooplankton is no doubt microzooplankton, perhaps as much as $50 \%$ (Calbet and Saiz, 2005) but what portion is say ciliates or dinoflagellates is not known.

It may be time to re-evaluate our methods. Consider the recent exchange of views concerning the ${ }^{14} \mathrm{C}$ method (Banse, 2002; Marra, 2003; Moigis, 2004). The old arguments were never settled. Carbon fixation rates, estimated as rates of particulate carbon production are likely underestimates because DOC production by phytoplankton as well as grazing in the incubation bottles are ignored (recall that according to Calbet and Landry about $64 \%$ of production is consumed per day by microzooplankton in bottle incubations!). If dilution experiments overestimate carbon consumption and ${ }^{14} \mathrm{C}$ methods under-estimate carbon fixation, more carbon may be available for export from the surface layer than presently appreciated.

Acknowledgements. This work is a contribution of the PECHE project, part of the French national program, "PROOF" (Processus biogéochimiques dans l'Océan et Flux). Financial support was provided by the C.N.R.S., the Université de Paris VI and the Université de Nice through the Erasmus program.

Edited by: V. Garcon

\section{References}

Ayukai, T. and Miller, D.: Phytoplankton biomass, production and grazing mortality in Exmouth Gulf, a shallow embayment on the arid, tropical coast of Western Australia, J. Exp. Mar. Biol. Ecol., 225, 239-251, 1998.

Banse, K.: Should we continue to measure 14C uptake by phytoplankton for another 50 years?, Limnol. Oceanogr. Bull., 11, 45-46, 2002.

Burkill, P. H., Edwards, E. S., and Sleigh, M. A.: Microzooplankton and their role in controlling phytoplankton growth in the marginal ice zone of the Bellinghausen Sea, Deep-Sea Res. II, 42, 1277-1290, 1995.

Calbet, A. and Landry, M. R.: Phytoplankton growth, microzooplankton grazing and carbon cycling in marine systems, Limnol. Oceanogr., 49, 51-57, 2004.

Calbet, A. and Saiz, E.: Assessing the strength of the ciliatecopepod link in marine ecosystems, Aquat. Microb. Ecol., in press, 2005.

Capriulo, G. M., Sherr, E. B., and Sherr, B. F.: Trophic behaviour and related community feeding activities of heterotrophic marine protists, in: Protozoa and their role in marine processes, edited by Reid, P. C., Turley, C., and Burkill, P. H., Springer-Verlag, Berlinm, 219-279, 1991.

Caron, D. A. and Dennett, M. R.: Phytoplankton growth and mortality during the 1995 Northeast Monsoon and Spring Intermonsoon in the Arabian Sea, Deep-Sea Res. II, 46, 1665-1690, 1999.

Caron, D. A., Dennett, M. R., Lonsdale, D. J., Moran, D. M., and Shalapyonok, L.: Microzooplankton herbivory in the Ross Sea, Antarctica, Deep-Sea Res. II, 47, 3249-3272, 2000.

Christaki, U., Giannakourou, A., Van Wambeke, F., and Grégori, G.: Nanoflagellate predation on auto- and heterotrophic pi- coplankton in the oligotrophic Mediterranean Sea, J. Plank. Res., 23, 1297-1310, 2001.

Dolan, J. R. and Simek, K.: Diel periodicity in Synechococcus populations and grazing by heterotrophic nanoflagellates: analysis of food vacuole contents, Limnol. Oceanogr., 44, 1565-1570, 1999.

Dolan, J. R., Vidussi, F., and Claustre, H.: Planktonic ciliates in the Mediterranean Sea: longitudinal trends, Deep-Sea Res. I, 46, 2025-2039, 1999.

Dolan, J. R., Gallegos, C. L., and Moigis, A.: Dilution effects on microzooplankton in dilution grazing experiments, Mar. Ecol. Prog. Ser., 200, 127-139, 2000.

Dolan, J. R., Sall, N., Metcalfe, A., and Gasser, B.: Effects of turbulence on the feeding and growth of a marine oligotrich ciliate, Aquat. Microb. Ecol., 31, 183-192, 2003.

Evans, G. T., and Paranjape, M. A.: Precision of estimates of phytoplankton growth and microzooplankton grazing when functional response of grazers may be non-linear, Mar. Ecol. Prog. Ser., 80, 285-290, 1992.

Fileman, E. and Burkill, P.: The herbivorous impact of microzooplankton during two short-term Lagrangian experiments off the NW coast of Galicia in summer 1998, Prog. Oceaonogr., 51, 361383, 2001.

Froneman, P. W. and Perissinoto, R.: Microzooplankton grazing and protozooplankton community structure in the South Atlantic and in the Atlantic sector of the Southern Ocean, Deep-Sea Res. I, 43, 703-721, 1996a.

Froneman, P. W. and Perissinoto, R.: Structure and grazing of the microzooplankton communities of the Subtropical Convergence and a warm-core eddy in the Atlantic sector of the Southern Ocean, Mar. Ecol. Prog. Ser., 135, 237-245, 1996 b.

Froneman, P. W. and Perissinoto, R.: Microzooplankton grazing in the Southern Ocean: Implications for the carbon cycle, P.S.Z.N. I. Mar. Ecol., 17, 99-115, 1996c.

Fuchs, B. M., Zubkov, M. V., Sahm, K., Burkill, P. H., and Amann, R.: Changes in community composition during dilution cultures of marine bacterioplankton as assessed by flow cytometric and molecular biological techniques, Environ. Microbiol., 2, 191201, 2000.

Gallegos, C. L.: Microzooplankton grazing on phytoplankton in the Rhode River, Maryland: nonlinear feeding kinetics, Mar. Ecol. Prog. Ser., 57, 23-33, 1989.

Gaul, W., Antia, A. N., and Koeve, W.: Microzooplankton grazing and nitrogen supply of phytoplankton growth in the temperate and subtropical northeast Atlantic, Mar. Ecol. Prog. Ser., 189, 93-104, 1999.

Gifford, D. J.: Impact of grazing by microzooplankton in the Northwest Arm of Halifax Harbour, Nova Scotia, Mar. Ecol. Prog. Ser., 47, 249-258, 1988.

Gifford, D. J., Fessenden, L. M., Garrahan, P. R., and Martin, E.: Grazing by microzooplankton and mesozooplankton in the highlatitude North Atlantic Ocean: spring versus summer dynamics, J. Geophys. Res., C4, 100, 6665-6675, 1995.

Hansell, D. A.: DOC in the global ocean carbon cycle, in: Biogeochemistry of marine dissolved organic matter, edited by Hansell, D. A. and Carlson , C. A., New York, Academic Press, 685-715, 2002.

Hernandez-Leon, S. and Ikeda, T.: A global assessment of mesozooplankton respiration in the ocean, J. Plank. Res., 27, 153-158, 2005. 
James, M. R. and Hall, J. R.: Microzooplankton grazing in different water masses associated with the Subtropical Convergence round the South Island, New Zealand, Deep-Sea Res. I, 45, 1689-1707, 1998.

Jeong, H. J.: The ecological role of heterotrophic dinoflagellates in marine planktonic community, J. Euk. Microbiol., 46, 390-396, 1999.

Kamiyama, T.: The impact of grazing by microzooplankton in northern Hiroshima Bay, the Seto Inland Seam, Japan. Mar. Biol., 119, 77-88, 1994.

Kirchman, D., Ducklow, H., and Mitchell, R.: Estimates of bacterial growth from changes in uptake rates and biomass, Appl. Environ. Microbiol., 44, 1296-1307, 1982.

Kuipers, B. R. and Witte, H. J.: Grazing impact of microzooplankton on different size classes of algae in the North Sea in early spring and mid-summer, Mar. Ecol. Prog. Ser., 180, 93-104, 1999.

Landry, M. R. and Hassett, R. P.: Estimating the grazing impact of marine microzooplankton, Mar. Biol., 67, 283-288, 1982.

Landry, M. R., Constantinou, J., and Kirshtein, J.: Microzooplankton grazing in the central equatorial Pacific during February and August 1992, Deep-Sea Res. II, 42, 657-671, 1995.

Lessard, E. J. and Murrell, M. C.: Microzooplankton herbivory and phytoplankton growth in the northwestern Sargasso, Sea. Aquat. Microb. Ecol., 16, 173-188, 1998.

Marra, J.: ${ }^{14} \mathrm{C}$ uptake by phytoplankton, now and in the future, Limnol. Oceanogr. Bull., 12, 1-3, 2003.

Moigis, A. G.: A comment on Marra's ${ }^{14} \mathrm{C}$ uptake now and in the future, Limnol. Oceanogr. Bull., 13, 4-6, 2004.

Mostajir, B., Dolan, J. R., and Rassoulzadegan, F.: Seasonal variations of pico- and nano-detrital particles (DAPI Yellow Particles, DYP) in the Ligurian Sea (NW Mediterranean), Aquat. Microb. Ecol., 9, 267-277, 1995.

Murrell, M. C. and Hollibaugh, J. T.: Microzooplankton grazing in northern San Francisco Bay measured by the dilution method, Aquat. Microb. Ecol., 15, 53-63, 1998.

Neuer, S. and Cowles, T. J.: Protist herbivory in the Oregon upwelling system, Mar. Ecol. Prog. Ser., 113, 147-162, 1994.

Olson, M. B. and Strom, S. L.: Phytoplankton growth, microzooplankton herbivory and community structure in the southeast Bering Sea: insight into the formation and temporal persistence of an Emiliania huxleyi bloom, Deep-Sea Res. II, 49, 5969-5990, 2002.
Paranjape, M.: Grazing by microzooplankton in the eastern Canadian arctic in summer 1983, Mar. Ecol. Prog. Ser., 40, 239-246, 1987.

Pitta, P., Giannakourou, A., and Christaki, U.: Planktonic ciliates in the oligotrophic Mediterranean Sea: longitudinal trends of stading stocks, distributions and analysis of food vacuole contents, Aquat. Microb. Ecol., 24, 297-311, 2001.

Putland, J. N.: Microzooplankton herbivory and bactivory in Newfoundland coastal waters during spring, summer and winter, J. Plank. Res., 22, 253-277, 2000.

Reckermann, M. and Veldhuis, M. J. W.: Trophic interactions between picophytoplankton and micro-and nanozooplankton in the western Arabian Sea during the NE monsoon 1993, Aquat. Microb. Ecol., 12, 263-273, 1997.

Rivkin, R. B., Putland, J. N., Anderson, M. R., and Deibel, D.: Microzooplankton bacterivory and herbivory in the NE subarctic Pacific, Deep-Sea Res. II, 46, 2579-2618, 1999.

Safi, K. A. and Hall, J. A.: Factors influencing autotrophic and heterotrophic nanoflagellate abundance in five water masses surrounding New Zealand, N. Z. J. Mar. Freshwat. Res., 31, 51-60, 1997.

Stoecker, D. K., Sieracki, M. E., Verity, P. G., Michaels, A. E., Haugen, E., Burkill, P. H., and Edwards, E. S.: Nanoplankton and protozooplankton during the JGOFS North Atlantic Bloom Experiment: 1989 and 1990, J. Mar. Biol. Assoc. UK, 74, 427443, 1994.

Tamigneaux E., Mingelbier M., Klein B., and Legendre, L.: Grazing by protists and seasonal changes in the size structure of protozooplankton and phytoplankton in a temperate nearshore environment (western Gulf of St.Lawrence, Canada), Mar. Ecol. Prog. Ser., 146, 231-247, 1997.

Verity, P. G. and Vernet, M.: Microzooplankton grazing, pigments, and composition of plankton communities during late summer in two Norwegian fjords, Sarsia, 77, 263-274, 1992.

Verity, P. G., Stoecker, D. K., Sieracki, M. E., and Nelson, J. R.: Grazing, growth and mortality of microzooplankton during the 1989 North Atlantic spring bloom at $47^{\circ} \mathrm{N}, 18^{\circ} \mathrm{W}$, Deep-Sea Res. I, 40, 1793-1814, 1993.

Verity, P. G., Stoecker, D. K., Sieracki, M. E., and Nelson, J. R.: Microzooplankton grazing of primary production at $140^{\circ} \mathrm{W}$ in the equatorial Pacific, Deep-Sea Res. II, 43, 1227-1255, 1996. 